\title{
IMPACTS OF SELECTED NACE INDUSTRIES' FOREIGN OWNERSHIP ON THE CZECH ECONOMY
}

\author{
Michaela Roubíčková, Tomáš Heryán
}

\section{Introduction}

This article is focused on the comparison of economic parameters of private companies under domestic control and private companies under foreign control (enterprises under state control are completely left out from the analysis), there is a clear relation to foreign direct investments (FDI). Although FDI pluses and minuses can be discussed in various contexts, empirical studies show that FDI are beneficial for the increase of performance of companies, industry and macroeconomic indicators. FDI bring benefits to a host country through several channels. Besides capital inflow itself, FDI are usually linked to the movement of specific tangible and intangible assets such as technology, managerial abilities and skills, corporate governance but also for instance the access to the network of companies interconnecting on foreign markets.

As soon as a foreign investor achieves a certain ownership level in a company in the host country and gains the control of company management, such an investor is willing to provide specific assets for the foreign company the use of which should bring profitability increase regardless of whether the company was built as a green field investment or it was taken over through microeconomic integration. As it is shown for example in The Economic Survey of Europe [5], FDI are just for this reason quite often regarded as an important catalyst in the economic transformation of economies in transition. The exact aim of current paper was to estimate whether the Czech companies' equity increasing and returns on equity's development have an impact on GDP's development in selected Czech business sectors.
Not only developing countries and economies in transition perceive the entry of foreign investors and capital inflow, know-how and other tangible and intangible assets as a catalyst for economic development. Thus a number of countries liberalized the access to foreign capital and even bearing in mind certain negative impacts on domestic enterprises, they tried and are trying to attract foreign investors. However, host countries of course analyze, after some time, the benefit and impact of foreign entities on domestic economy and assess whether resulting effects are rather negative or positive as well as the way how foreign entities act on domestic territory. Therefore our research objective is therefore the assessment of mutual relation between the change in equity and its return (ROE) and the impact of such indicators on the change in the growth rate of GDP with the emphasis on the fact whether the enterprises are of domestic or foreign origin. Therefore FDI have some several impacts at the Czech microeconomic level [8]. We argue then, it could be interesting to compare domestic and foreign ownership with weighted GDP growth rate in the Czech Republic. If foreign equity in the country and rentability of foreign owned companies affect GDP more than rentability of domestic companies, foreign ownership is more efficient for the Czech economy. From our point of view, microeconomic data in pooled sample could influence macroeconomy of the country. It motivates recent study, too.

\section{Literature Review}

However, the authors did not intend to limit the theoretical base just on the researches coming from mainland Europe countries, also because many foreign investors entering to Czech 
companies and setting up their subsidiaries on the territory of the Czech Republic come from the market system. That is why the following text brings the survey of selected studies that are relevant for this paper and intentionally cover a broader spectrum of economies than just those belonging to the mainland European model.

A significant number of analyses were carried out on the data of US companies that are a key representative of the Anglo-American model. For example Wheeler [23] or Dworin [5] examined investor entry to US enterprises and showed that foreign-owned subsidiaries in the USA had reported lower profitability than domestic companies. Such conclusions were confirmed by Grubert, Goodspeed and Swenson [8] who published the data showing that in 1987 profitability of $37 \%$ of all non-financial foreign companies was in the interval of $-2.5 \%$ to $+2.5 \%$ while only $27 \%$ domestic ones were in this interval. On the other hand Doms and Jensen [4] found out that foreign-owned US companies were more productive than the domestic ones but were, on average, less productive that multinational companies with an American parent company. Using the data of US companies in manufacturing industry, the FDI impact was analyzed for instance by Desai, Foley and Hines [3]. For forecasting the changes in foreign investments, they applied company specified weighted average of foreign GDP growth in the interaction with geographically specified foreign investments distribution. According to the authors, the weighted average of foreign GDP growth is a strong predictor of subsequent foreign investments of US companies. According to them, foreign growth predicts the growth of foreign investments by foreign companies focused on satisfying the needs on host markets. Their conclusions do not support the thesis that increased activity of foreign companies displaces the activity of domestic companies acting in the same field.

Min and Smyth [5] argue that firms with better corporate governance arrangements will be better placed to absorb technological transfer from foreign equity ownership for two main reasons. First, firms with better corporate governance will have more transparent decision-making processes. Improved corporate governance limits potential for conflict of interest and improves the disclosure of information.
Increased disclosure of information makes it easier for stakeholders to assess, and oversee management and keep management accountable. Second, as one metric of corporate governance, it is argued that outside directors are more independent than their inside counterparts. The reason is that their future career does not depend on the professional advancement of their board colleagues as much. Inside directors might be less willing to put pressure on management because they fear it might hurt their own career prospects through creating enemies within the firm, particularly if there are adverse short-term side effects such as job losses. Outside directors, on the other hand, will be less concerned with internal politicking and can exert pressure on management to make decisions designed to put the technological transfer from foreign ownership to best use.

Among the mainland Europe type of countries also Japan is included. Sakakibara and Yamawaki [18] focused on monitoring the profitability determinants of subsidiaries of Japan multinationals in 1990-1996. The results of their researches show that the determinants affecting the profitability of subsidiaries differ depending on a host country. This suggests that the economic and institutional factors specific for host regions can significantly affect the profitability performance of foreign subsidiaries. Unlike the size that affects subsidiary profitability significantly in all countries, other effects such as experience, local supply chains, local sales and macroeconomic conditions affect the performance of subsidiaries in a different way depending on the host country.

$\mathrm{He}$ et al. [5] investigate the relation between foreign ownership and the informativeness of stock prices in 40 markets. They show that foreign ownership is positively related to price informativeness, measured by probability of informed trading and price nonsynchronicity which reflects firm-specific variations in stock returns. They also find a stronger association between stock returns and future earnings innovations for firms with higher foreign ownership. But in the Czech Republic there is the bank based type of financial system. Therefore we will investigate return on equity (ROE), not relationship to stock prices.

It is apparent from the above that a large number of empirical studies were published 
dealing with the whole range of issues related to FDI. Nevertheless, as Jarolím [12] suggests, it is relatively striking that only a few of them deal with FDI impacts on Central and Eastern Europe countries despite the fact that foreign capital inflow is regarded as one of the key factors of transition process development. The author in his study analyzed the data of manufacturing sector in 1993-1998. He focused on the comparison of the indicators such as productivity of labor, external orientation and investment activities of foreign- and domesticowned companies and tried to find the answer to the question which group achieves higher growth rate of production factors. Additional objective was to examine the existence of spillover effect. His conclusions showed that foreign-owned companies report higher labor productivity, export larger part of production volume and invest more funds related to total sales. However, these conclusions are true just in case that company size is not considered. Otherwise the results show that foreign-owned companies reach only $90 \%$ productivity level. The author did to manage to prove the existence of spillover effect.

As to the mainland Europe territory for instance the researches by Arndt and Mattes [1] compare the size and productivity of domestic and foreign German companies and concluded that foreign MNCs are smaller and more productive. The rate of employment in MNC was by $15 \%$ lower while they reported total productivity factor (TFP) higher by $5.6 \%$ to $6.5 \%$. MNC labor force productivity was higher even by $20 \%$. They also proved that while the effect of ownership change on employment is not significant, the effect of the change on labor force productivity and total productivity is positive. On the other hand the study by Gelübcke and Annex [6] showed that foreigncontrolled companies in the sector of services doing business in Germany were characterized by employment higher by $50 \%$, more than $60 \%$ higher wages and by $2 \%$ to $6 \%$ lower return on sales as compared with domestic companies.

The studies conducted in emerging economies are important, too. For example Yasar and Paul [24] compared in their analysis the performance of the companies with foreign ownership with the performance of purely domestic industrial companies. For their analyses they used the data of five emerging economies, namely Poland, Moldova, Tajikistan, Uzbekistan and Kyrgyzstan. They found out unambiguously that foreign-owned companies report higher productivity, capital use intensity, share of export and import, and employment and wage level. They also found that industry with the presence of foreign subsidiaries of multinational companies shows performance improvement of domestic companies. These findings support the hypothesis that foreign companies bring technology and skills, access to foreign markets and new job opportunities that increase the performance of host country companies. This also indicates that the connection with foreign-owned companies should be supported because it leads to the increase of industry productivity and competitiveness in emerging economies.

Gallová [6] examined the impact of FDI on countries of Balkan and countries of Vysegrad 4 Group. Result of her research is that in these countries in period 1993-2009 was not detected any positive effect of domestic investment by foreign ones. On the contrary, FDI had negative influence and crowd out the domestic investment. On the other hand, Szanyi [20] shows in his study that foreignowned companies doing business in Hungary reported worse financial results than domestic companies, especially in the first years after the investment was made.

The impact of FDI on selected (not macroeconomic) indicators is addressed by a number of studies. Large part of them focuses on the effects on domestic companies caused by FDI outflow from the country. A number of others keep track of FDI inflow per the number of employees and wage level (for example Demel and Potužáková [2]). However, there are studies that (similar to this article) deal with the impact of direct foreign investments inflow on the profitability of companies. Studies come from various parts of the world that differ not only in terms of economic development but also as to the type of their financial system and thus the type of ownership structure dominant model. The Czech Republic is, as for instance Roubíčková [16] shows, a typical mainland European country with a strong banking system and the capital market is not a key source of funding (currently - in March 2013 - there are 30 stocks listed on the Prague Stock Exchange). The mainland European management model is 
a characteristic insider system representing a higher level of influence on company management from the inside. This is possible because in this system there is a possibility (and conditions) for the occurrence of majority or substantial ownership. The fact that quite often it is foreign majority ownership is shown by this analysis.

In the Czech Republic, also Hanousek, Kočenda and Švejnar [9] carried out a research. Their analysis (conducted for the years of 1996-1999) showed that as to the companies privatized within the large privatization the type of ownership does not play a significant role. The authors take into account not only private foreign and domestic ownership but also state ownership. In their opinion, concentrated foreign ownership has positive impact only when it is applied to industrial enterprises and the concentrated foreign ownership increases sales revenues while on the contrary, more or less the same concentrated domestic ownership over a given period decreased labor cost. The authors analyzed the companies the stocks of which were traded on the Prague Stock Exchange in 1996.

The performance comparison of companies before and after takeover was carried out by Jurajda and Stančík [13]. The authors regarded as foreign-owned those companies in which a foreign entity had more than $10 \%$ stake in subscribed capital. More than 4,000 manufacturing sector companies in 1995-2005 were monitored while an important milestone was 1997 when a lot of companies were taken over after privatization had been completed. The analysis suggested that the impact of foreign capital entry is positive in particular in nonexport manufacturing fields. In other areas its influence is small.

The impact of foreign owners on selected indicators of companies was addressed also by Roubíčková [17]. The aim of the paper was to assess the impact of being part of an institutional subsector on the development of profitability and indebtedness of construction sector companies. Thus the development of indicators of foreign- and domestic-owned companies since the beginning of 2007 through to the middle of 2011 was analyzed. The analysis showed that ROE of private foreign-controlled companies is not, in the long term, as high as expected as compared to private domestic- controlled companies. It was not even proved that such companies would bring higher added value to their owners in the long term. Although the share of equity to total assets was lower in foreign-controlled companies (they employ cheaper financial sources in the long term), this fact does not result unambiguously in higher profitability.

\section{Data and Methodology}

For the analysis, the data from corporate financial analyses in 2007-2012 published by the Ministry of Industry and Trade was used. It was quarter data for five business sectors due to its NACE categorization including also its GDP. Analyzing industries are (i) Mining and quarrying, (ii) Manufacturing, (iii) Electricity, gas, steam and air conditioning production and its supply, (iv) Water supply, sewerage, waste management and remediation activities, and (v) Construction. For other NACE sectors their GDP values are not collected. Due to that reason we have just chosen these five NACE industries for our analysis. We have analyzed time series from $1 / 2007$ to $4 / 2012$ period.

The Czech Republic is a small open economy with a significantly higher number of private enterprises under foreign control (and not only in the period 2007-2012) in selected sectors, as shown in Fig. 1.

Equity had changed and also numbers of companies had changed in each NACE industry in our estimated period. Therefore we have formulated average equity growth rate by using equation (1):

$$
a e_{i t}=\left(\log \left(\frac{E_{i t}}{n o_{i t}}\right)-\log \left(\frac{E_{i(t-1)}}{n o_{i(t-1)}}\right)\right) \cdot 100,
$$

where $a e_{i t}$ means average equity growth rate of $i$ NACE business industries in time $t, E_{i t}$ means equity and $n o_{i t}$ is number of selected companies.

We have examined relation between domestic/foreign equity, rentability of these companies and GDP. Due to that we have to examine also weighted GDP. Weights depend on changes in foreign equity on total amount of companies' equity in the Czech Republic. Weighted GDP growth rate have been calculated by equation (2):

$$
w h d p_{i t}=\left(\log \left(w_{i t \frac{z}{f+d}} \cdot H D P_{i t}\right)-\log \left(w_{i(t-1) \frac{z}{f+d}} \cdot H D P_{i(t-1)}\right)\right) \cdot 100,
$$




\section{Fig. 1: Number of companies in selected sectors}

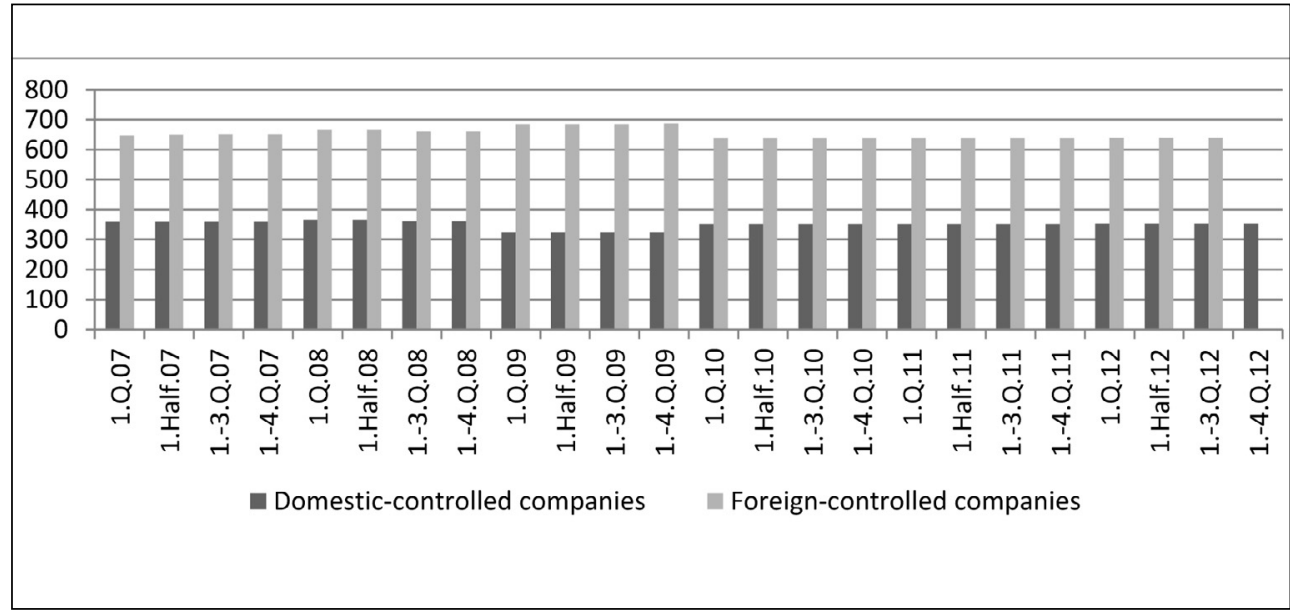

Source: Own based on Ministry of Industry and Trade's financial analysis

where $w h d p_{i t}$ means weighted GDP growth rate of $i$ NACE business industries in time $t$, and

finally in GDP weights $w_{i t} \frac{z}{f+d}$ symbol $z$ is equity

which changes from $f$ for foreign to $d$ for domestic equity.

Min and Smyth [5] also verify the hypothesis weather an increased foreign equity ownership has a positive effect on firm productivity. They employ the GMM method of instrument variable estimation to address the possible endogeneity problem associated with the appointment of outside directors in robustness checks, too. Varum and Rocha [5] use in their estimation a dummy variable which allows distinguishing between foreign owners and domestic owners. Against to them we employ panel EGLS estimation with cross section weights and differ between domestic and foreign owners. Our panel regression model is then described as follows by next equation (3) separate for domestic and foreign owned equity:

$$
w h d p_{i t}=\alpha+\beta_{1} \cdot a e_{i t}+\beta_{2} \cdot R O E_{i t}+A R(1)+\varepsilon_{i t},
$$

where weighted GDP growth rate $w h d p_{i t}$ is endogenous dependent variable, exogenous independent variables are average equity growth rate $a e_{i t}$ and $R O E_{i t}$ which means return on equity of $i$ NACE business industries in time $t, \alpha$ is constant and $\varepsilon_{\text {it }}$ means residuals. We also have to put auto-regression $A R(1)$ into our model to optimize autocorrelation of residuals.

\section{Discussion on Empirical Results}

Due to aspect of the companies' size and its possible effect on the profitability of firms it is used weighted GDP per share of the both, foreign and domestic owned companies. Our sample has estimated whether foreign-owned corporations differ significantly from domestic companies in these aspects. The results clearly show that foreign-owned companies have a positive impact on GDP's growth rate through both, an increase in equity and increase ROE. In the case of domestic firms positive impact of ROE's change was not demonstrated. There is the only one proven positive impact of the domestic equity's change on GDP.

According to the fact that the other parameters have not been significantly extended (we have tested also changes within pooled sample of equity per assets, weighted costs of capital, risky free rate, market risk premium), the authors believe that the main reason of the above results may be in foreignowned companies tendency to repatriate their profits. Repatriation of profits is a logical consequence of the efforts of foreign investors 


\begin{tabular}{|c|c|c|c|c|}
\hline Tab. & $\begin{array}{l}\text { Interpretati } \\
\text { variable) }\end{array}$ & sion resu & ted GDP gro & dependend \\
\hline \multirow{6}{*}{ 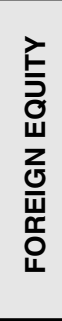 } & $\alpha$ & $\beta_{1}$ & $\beta_{2}$ & AR(1) \\
\hline & -0.9272 & 0.5006 a & $0.2653 \mathrm{~b}$ & $-0.1945 b$ \\
\hline & $(0.0538)$ & $(0.0000)$ & $(0.0477)$ & $(0.0352)$ \\
\hline & 0.4755 & 0.0219 & 0.1317 & 0.0912 \\
\hline & Adj. $R^{2}$ & S.E. of reg & Durbin-Wats. & \\
\hline & 0.8507 & 9.6415 & 1.7794 & \\
\hline \multirow{6}{*}{ 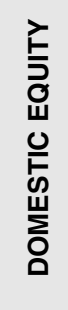 } & $\alpha$ & $\beta_{1}$ & $\beta_{2}$ & $\operatorname{AR}(1)$ \\
\hline & -0.2979 & 0.7336 a & 0.0948 & -0.2738 a \\
\hline & $(0.7069)$ & $(0.0000)$ & $(0.6671)$ & $(0.0042)$ \\
\hline & 0.7901 & 0.0583 & 0.2427 & 0.0936 \\
\hline & Adj. $R^{2}$ & S.E. of reg & Durbin-Wats. & \\
\hline & 0.7019 & 21.1511 & 2.1016 & \\
\hline
\end{tabular}

Note: $a, b$ denote significance at $1 \%, 5 \%$

Source: Authors' calculations

to realize returns. The repatriation is necessary to show a profit also to the investors. It is possible that foreign-owned firms are therefore more willing to show a profit than domestic companies. Domestic companies can also be desiring to show a lower profit due to lower tax liability. It would confirm that the increase in equity has a positive effect on GDP in both foreign-owned and domestic companies, too.

Technically, there is no multicolinearity among all exogenous. The Appendix chart shows that there is not also significant correlation between residuals and exogenous in our models. Therefore we reject the hypothesis of heteroskedasticity problem within residuals. Even if there is little bad meassure of positive (foreign) and negative (domestic) autocorrelation in residuals, our models are in good condition. All timeseries and panel data have been stacionary at their first differences.

A foreign direct investment can be regarded as an investment in which a foreign investor owns 10 or more percent of stock (share) or rights to vote. As part of a direct foreign investment, besides a share in subscribed capital, also reinvested earnings and other capital can be regarded and that comprises credit relations with the foreign investor. Unless this share exceeds $50 \%$, the companies with foreign ownership are included in the public or private national sector [19]. Thus foreign control is defined as a direct or indirect (through interconnected entities) control of more than a half of shareholders' voting rights or of more than a half of shares. Control country is determined according to the headquarters residence of the top control institutional entity, e.g. the company. That is the company that itself is not further controlled by any other institutional entity [13].

In general, FDI are formed by a contribution of foreign investors to subscribed capital (SC) of domestic companies, by reinvested earnings (RE) of the earnings (or their part) generated by the companies and reinvested in the business on domestic territory, and last but not least by inter-company credits between the foreign (parent) company and the domestic company (subsidiary). Unlike the two remaining components of direct foreign investments, the specifics of reinvested earnings are that they do not really mean real inflow of foreign capital on foreign exchange market. Thus reinvested earnings of foreign companies are the value that is comprised in the balance of payments but does not have any impact on foreign exchange market and consequently on Czech crown exchange rate. Most of the data in the balance of payments shows the transactions between country residents and foreign entities within which domestic currency is exchanged for foreign currency. Such transactions are then reflected in the changes in demand and supply on the foreign exchange market. 


\section{Fig. 2: Inflow of direct foreign investments to selected sectors in 1993-2012}

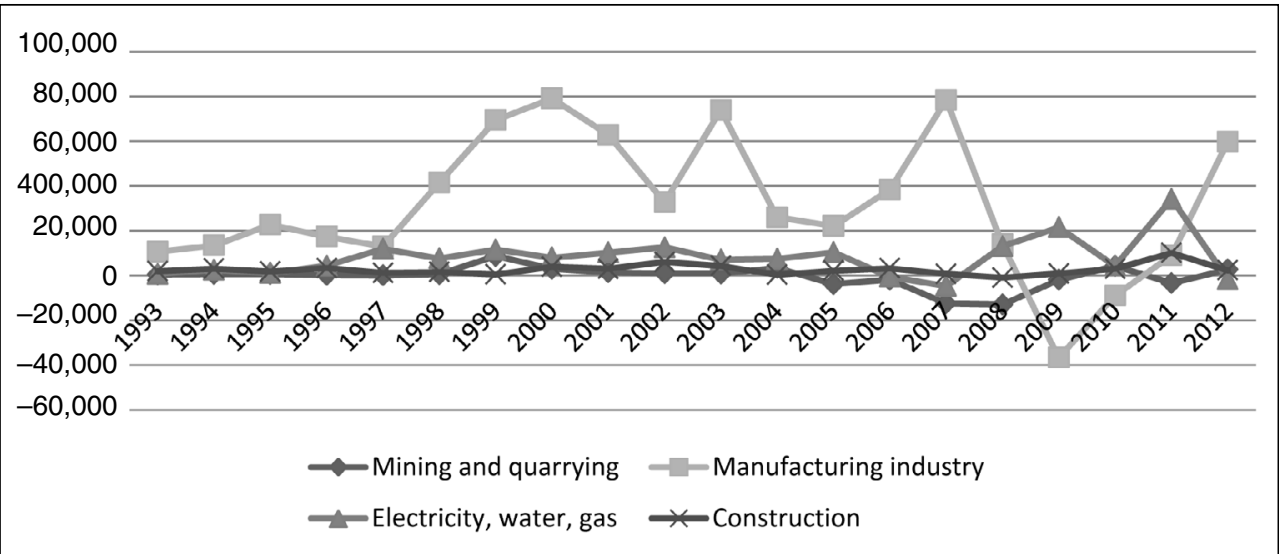

Source: Own based on ČNB - Inflow of direct foreign investments to selected sectors as per sectors and countries - timeline

Fig. 2 shows the inflow of foreign direct investments to selected sectors in 1993-2012 according to the information of the Czech National Bank. By 1997, the data include just direct foreign investments to subscribed capital, since 1998 their part has been reinvested as reinvested earnings and other capital. Sector division differs from the one used for the analysis in this article because, till 2009, CNB still applied the original segmentation as per the industry classification of economic activities (OKEC). The graph shows that the largest FDI inflow was recorded in manufacturing industry where the largest year-to-year decrease can be seen in 2008 and 2009, namely $-64,575$ mil CZK and $-50,540$ mil CZK which, just in 2009 , represented $-365 \%$.

Majority ownership of companies in a given industry, i.e. institutional sector was regarded as the key factor. Institutional sector represents a set of institutional units that are characterized by their similar focus and objectives and are used to analyze income creation and distribution. Sectors are further divided into subsectors. In case of non-financial enterprises which this article deals with the split is made depending in the entity that controls and runs them. Thus the enterprises under state control, private enterprises under domestic control and private enterprises under foreign control are distinguished. Although the split into individual subsectors cannot be made quite accurately as the subsectors mutually overlap in some cases and part of national public and private sector enterprises can be owned by foreign owners, but even so it has significant explanatory power.

The earnings of the foreign company can either be repatriated as dividends back to the parent company or reinvested in the domestic country and thus the original foreign investment can be increased. In both the cases such a transaction is recorded as a cost in the current account income balance item but only dividends have real impact on external imbalance of the country as they increase the demand for foreign investor currency on the foreign exchange market. Reinvested earnings remain in domestic economy and due to the double-entry principle of balance of payments item posting they are recorded as the inflow of direct foreign investments to the country. Repatriation - the repatriation restrictions and the amount and method of taxation of profits may therefore be an important factor in the actual decisionmaking about the allocation of investment, such as Szarowská [21] presents.

The inflow of direct investments to the Czech economy as a whole is fluctuating. For instance in 1999-2002 it was growing each year, on average, roughly by one tenth (even at relatively high basic values over the last year) and the average yearly inflow in this period was 
225.9 bil. CZK. Such a level indicated a world record of the Czech Republic as to the volume of incoming investments per capita. Over this period, reinvested earnings grew each year, on average, by $41 \%$. However, in 2003 , substantial year-to-year decrease of direct foreign investments by $74 \%$ occurred while the reduction of reinvested earnings volume was just by $1.7 \%$. In 2003, direct investments reached 72.9 bil. CZK. In 2005, until then the highest ever inflow of direct foreign investments to the Czech economy was recorded with the net balance of 279.2 bil. CZK. - out of that capital inflow and reinvested earnings reached 262.5 bil. CZK, the rest being other investments. In 2006, direct foreign investments to the Czech Republic dropped year-to-year by 144.5 bil. CZK (i.e. by $52 \%)$. Capital entries to Czech companies slumped by 148.8 bil. CZK. However, foreign investors reinvested back to the businesses on the territory of the Czech Republic the earnings in the amount of 82.1 bil. CZK which represented by 4 bil. CZK more than in 2005. Contribution of this study is also examining relationships in period 2007-2011.

The aim of the article was to estimate whether the Czech companies' equity increasing and returns on equity's development have an impact on GDP's development in selected Czech business sectors. In future research we will pay more attention to investigation whether foreignowned firms perform significantly better than domestically-owned firms. We will try to estimate the relations between ROE, ROA and the predictor variables which are number of employees, labor productivity, equity, $R \& D$ expenses as a percentage of sales and investments.

\section{Concluding Remarks}

Our study has proved positive impacts of foreign ownership on GDP in the Czech Republic. Foreign-owned companies have a positive impact on GDP growth rate through both increase in equity and increase in return on equity (ROE) of Czech firms. In the case of domestic-owned firms the positive impact of ROE change was not demonstrated. Due to the fact that our research has investigated domestic-owned as well as foreign-owned companies, there should be a relation to the FDI issues. Our results have definitely suggested a theoretical assumption of most relevant literature that FDI support economic growth and profitability of selected business branches.

According to the theoretical assumptions in the article, foreign-owned companies should seek higher profitability in order to outweigh the risks associated with the entry to foreign economy. Nevertheless, one of the reasons for this phenomenon may be the size of firms under foreign control and their ability to create economies of scale. Large foreign companies may then also weaken their domestic operation in the sector or vice versa strengthen their activities.

In general, the main reasoning behind the paper conclusions related to foreign-owned companies may be their tendency to repatriate profits. While foreign-owned companies are motivated to maximize their profits which are then repatriated abroad to increase wealth of their parent companies, domestic-owned companies do not prefer maximizing profitability due to their majority ownership while their, managers are able to get information and realize their strategic goals more easily. However, one question still remains to what extent this issue is affected by the risk that domestic companies could report lower profit due to lower tax liability, or just by the differences between taxes in the Czech Republic and abroad.

\section{References}

[1] ARNDT, C. and MATTES, A. The Impact of Inward FDI and Foreign Ownership on the. Performance of German Multinational Firms [online]. Graz: Karl Franzens Universität, 2008 [cit. 201301-02]. Available from: http://www.uni-graz.at/ socialpolitik/papers/Mattes.pdf.

[2] DEMEL, J. and POTUŽÁKOVÁ, Z. FDI and the Liberec Region: The case of the labour market. E+M Ekonomie a Management. 2012, Vol. 15, Iss. 4, pp. 4-18. ISSN 1212-3609.

[3] DESAI, M.A., FOLEY, C.F. and HINES, J.R. Foreign Direct Investment and the Domestic Economic Activity. NBER Working paper [online]. Cambridge (MA), 2007. No. 11717 [cit. 2013-02-02]. Available from: http://www.nber.org/papers/ w11717.pdf?new_window=1.

[4] DOMS, M.E. and JENSEN, J.B. Comparing Wages, Skills, and Productivity between Domestically and Foreign Owned Manufacturing Establishments in the United States. In: BALDWIN, R., LIPSEY, R. and RICHARDSON, J.D. (Eds.). 
Geography and Ownership as Bases for Economic Accounting. Chicago: Chicago Press, 1998. ISBN 9-780-2260-365-40.

[5] DWORIN, L. Transfer pricing issues. National Tax Journal. 1990, Vol. 43, Iss. 3, pp. 285-291. ISSN 0028-0283.

[6] GALLOVÁ, Z. Foreign Direct Investment in Selected Countries of Balkan and in the Visegrad Group Countries: Does it Crowd out or Crowd in Domestic Investment? In: STAVÁREK, D., VODOVÁ, P. (Eds.) Proceedings of 13th International Conference on Finance and Banking. Karviná: Silesian University, School of Business Administration, 2012. pp. 90-97. ISBN 978-80-7248-753-0. [7] GELÜBCKE, J. and ANNEX, W. Foreign Ownership and Firm Performance in German Services: First Evidence based on Official Statistics [online]. Lueneburg: Leuphana University Lueneburg, 2011 [cit. 2013-01-02]. Available from: http://204.3.197.155/ETSG2011/Papers/ Geluebcke.pdf.

[8] GRUBERT, H., GOODSPEED, T. and SWENSON, D. Explaining the low taxable income of foreign-controlled companies in the United States. Studies in international taxation. Chicago: University of Chicago Press, 1993. pp. 237-275. ISBN 0-226-29701-2.

[9] HANOUSEK, J., KOČENDA, E. and MAŠIKA, $M$. Firm efficiency: Domestic owners, coalitions, and FDI. Economic Systems. 2012, Vol. 36, Iss. 4, pp. 471-486. ISSN 0939-3625.

[10] HANOUSEK, J., KOČENDA, E. and ŠVEJNAR, J. Origin and Concentration: Corporate Ownership, Control and Performance. CERGE WP [online]. Prague: CERGE-EI, 2005 [cit. 201303-15]. Available from: http://www.cergeei.cz/pdf/wp/Wp259.pdf. ISSN 1211-3298.

[11] HE, W., LI, D., SHEN, J. and ZHANG, B. Large foreign ownership and stock price informativeness around the world. Journal of International Money and Finance. 2013, Vol. 36, pp. 211-230. ISSN 0261-5606.

[12] JAROLÍM, M. Foreign Direct Investment and Productivity of Firms. Czech Journal of Economics and Finance. 2000, Vol. 50, Iss. 9, pp. 478-487. ISSN 0015-1920.

[13] JURAJDA, Š. and STANČíK, J. Foreign Ownership and Corporate Performance: The Czech Republic at EU Entry. CERGE WP [online]. Prague: CERGE-EI, 2009 [cit. 2013-03-15]. Available from: http://www.cerge-ei.cz/pdf/wp/ Wp389.pdf. ISSN 1211-3298.
[14] MIN, B.S. and SMYTH, R. Corporate governance, globalization and firm productivity. Journal of World Business. 2014, Vol. 49, Iss. 3, pp. 372-385. ISSN 1090-9516.

[15] Prímé zahraniční investice za rok 2009 [online]. Praha: Czech national bank, c2010 [cit. 2012-02-22]. Available from: http://www.cnb.cz/ miranda2/export/sites/www.cnb.cz/cs/statistika/ platebni_bilanc/stat/publikace_pb/pzi/PZ I_2009_CZ.pdf.

[16] ROUBÍČKOVÁ, M. Vliv corporate governance na dividendovou politiku akciových společností v České republice [Chap. 3]. In: RŮČKOVÁ, P. Corporate governance $v$ České republice. 1st ed. Praha: Professional Publishing, 2008. pp. 73-100. ISBN 978-80-86946-0.

[17] ROUBÍČKOVÁ, M. Vliv institucionálního sektoru na vývoj vybraných ukazatelů. Scientific Papers of the University of Pardubice. 2012, Vol. 25, Iss. 2, pp. 147-156. ISSN 1211-555X.

[18] SAKAKIBARA, M. and YAMAWAKI, H. What Determines the Profitability of Foreign Direct Investment? A Subsidiary-Level Analysis of Japanese Multinationals [online]. Claremont: Claremont Graduate University, 2005 [cit. 2013-01-02]. Available from: http://www.cgu.edu/PDFFiles/ Faculty/Yamawaki/Profit\%2012-14-05.pdf.

[19] SPĚVÁČEK, V. Sektorová analýza vývoje české ekonomiky. WORKING PAPER č. 16/2010 [online]. Praha: Centrum výzkumu konkurenční schopnosti české ekonomiky, 2010 [cit. 2012-03-23]. Available from: https://is.muni.cz/do/econ/soubory/ oddeleni/centrum/papers/16Spevacek.pdf? fakulta=1456. ISSN 1801-4496.

[20] SZANYI, M. Foreign Direct Investments in Small Business in Transition Economies [online]. Warsaw: Central European University, 1998 [cit. 2013-03-15]. Available from: http://www.isn. ethz.ch/isn/Digital-Library/Publications/Detail/ ?ots591=0c54e3b3-1e9c-be1e-2c24a6a8c7060 $233 \&$ Ing $=$ en\&id=128892. ISBN 83-7178-087-7.

[21] SZAROWSKÁ, I. Jak vysoké je daňové zatížení? Acta academica karviniensia. 2011, No. 2, pp. 196-207. ISSN 1212-415X.

[22] VARUM, C.A. and ROCHA, V.C.B. Do foreign and domestic firms behave any different during economic slowdowns? International Business Review. 2011, Vol. 20, Iss. 1, pp. 48-59. ISSN 0969-5931.

[23] WHEELER, J.E. An academic look at transfer pricing in a global economy. Tax Notes. 1988, pp. 87-96. ISSN 0270-5494. 
[24] YASAR, M. and PAUL, C.J.M. Firm Performance and Foreign Direct Investment: Evidence from Transition Economies [online]. Economics Bulletin. 2007, Vol. 15, No. 21 [cit. 2013-03-12], pp. 1-11. Available from: http://www.accessecon. com/pubs/EB/2007/Volume15/EB-07050003A.pdf. ISSN 1545-2921.
Ing. Michaela Roubíčková, Ph.D.

Silesian University in Opava

School of Business Administration in Karviná

Department of Finance and Accounting roubickova@opf.slu.cz

Ing. Tomáš Heryán, Ph.D.

Silesian University in Opava

School of Business Administration in Karviná

Department of Finance and Accounting heryan@opf.slu.cz 


\section{Ekonomika a management}

\section{Appendix:}

\section{Tab. 2: Multicolinearity of regressors}

\section{Correlation}

t-Statistic

Probability

\begin{tabular}{lcc} 
& $\begin{array}{c}\text { Foreign } \\
R O E_{i t}\end{array}$ & $\begin{array}{c}\text { Domestic } \\
R O E_{i t}\end{array}$ \\
\hline$R O E_{i t}$ & 1.0000 & 1.0000 \\
& ---- & ---- \\
& ---- & ---- \\
$a e_{i t}$ & & \\
& -0.0251 & -0.1327 \\
& -0.2665 & -1.4228 \\
& 0.7903 & 0.1576
\end{tabular}

\section{Tab. 3: Heteroskedasticity of residuals}

\section{Correlation}

$t$-Statistic

Probability

$R O E_{i t}$

$-0.0013$

$-0.0757$

$-0.0132$

$-0.7891$

0.9895

0.4318

$a e_{i t}$

$-0.0929$

0.0291

$-0.9693$

0.3025

0.3346

0.7628 


\section{Abstract}

\section{IMPACTS OF SELECTED NACE INDUSTRIES' FOREIGN OWNERSHIP ON THE CZECH ECONOMY \\ Michaela Roubíčková, Tomáš Heryán}

The aim of the current paper was to estimate whether the Czech companies' equity increasing and returns on equity's development have an impact on GDP's development in selected Czech business sectors. Contribution of our study to foreign direct investment and firm performance the matters is using quarterly frequency data to examine relationship between foreign ownership and quarterly economic growth in selected NACE business sectors. Hanoušek et al. [9] argue that Foreign Direct Investments (FDI) have some several impacts at the Czech microeconomic level. We argue then, it could be interesting to compare domestic and foreign ownership with weighted GDP growth rate in the Czech Republic. If foreign equity in the country and rentability of foreign owned companies affect GDP more than rentability of domestic companies, foreign ownership is more efficient for the Czech economy. From our point of view, microeconomic data in pooled sample could influence macroeconomy of the country. It motivates recent study. We are estimating panel regression models with cross section weights. Our endogenous variable is weighted GDP growth rate in pooled data of all our selected business industries. Our exogenous variables are average equity growth rate and growth rate of return on equity (ROE), both in pooled sample of selected Czech industries. This study proved positive impacts of foreign ownership on GDP in the Czech Republic. Foreign-owned companies have a positive impact on GDP growth rate through both increase in equity and increase of ROE of Czech firms. In the case of domestic-owned firms the positive impact of ROE change was not demonstrated.

Key Words: Foreign and domestic ownership, foreign direct investments, panel regression.

JEL Classification: G34, M12.

DOI: 10.15240/tul/001/2014-4-005 